\title{
Nest Association between Camponotus fallax (Hymenoptera: Formicidae) and Vespa crabro (Hymenoptera: Vespidae) in Central Iberian Peninsula
}

\author{
C Mora-Rubio, Jl PÉREZ-Bote, J Muriel \\ Department of Zoology, University of Extremadura, Badajoz, Spain
}

\section{Article History}

\section{Edited by}

Evandro N. Silva, UEFS, Brazil

Received 26 March 2019

Initial acceptance 04 August 2019

Final acceptance 05 August 2019

Publication date 14 November 2019

\section{Keywords}

Camponotus fallax, ants, European hornet, Vespa crabro, nest association.

\section{Corresponding author}

Carlos Mora-Rubio

Department of Zoology

University of Extremadura

Av. Elvas s/no, 06006, Badajoz, Spain.

E-Mail: cmorarub@alumnos.unex.es

Diverse authors have reported a large number of cases about interactions between Formicidae and Vespidae (e.g. Rusina, 2011). Most interactions are related with cases of predation by ants on wasp nests or directly on solitary species (e.g. Schatz et al., 2006). These cases are more frequent in tropical areas than in temperate areas (Jeanne, 1979). The observations in Europe are mostly related to attacks by ants on paper wasp (Polistes sp.) nests (e.g.Turillazzi \& Ugolini, 1979; Rusina, 2011; Kozyra \& Baraniak, 2016; Pérez-Bote $\&$ Mora-Rubio, 2018). Paper wasps build open and exposed nests that resemble an upside-down umbrella, whereas Vespa nests are protected by a carton envelope with a single opening towards the outside. The biological function of this envelope is to protect the colony and maintain an adequate microclimate, constant humidity and temperature (Klingner et al., 2005), being specially suggested as an adaptation to reduce ant predation (Jeanne, 1975). Other interactions between these groups have been described as mutualisms or commensalisms, being especially common in tropical areas. Thereby, several authors have reported that some species of arboreal wasps

\begin{abstract}
Because social wasps often defend their nests by inflicting painful stings or bites, some animals associate with them looking for protection against potential predators. Some neotropical vespids are known to maintain associations with other insect and vertebrate taxa, such as birds and bats, however there are not previous records about associations between ants and hornets in Europe. In this study, we reported the first case of association between the arboreal ant Camponotus fallax and the European hornet Vespa crabro in Europe. The observations were made in Central Spain, where two colonies of $C$. fallax were found in two different avian nest-boxes inhabited by $V$. crabro when spotless starlings finished their breeding season. The reasons of this possible association are also discussed.
\end{abstract}

(e.g. Polybia rejecta and Synoeca virginea) build their nests close to Azteca chartifex nests in French Guiana and Brazil (Somavilla et al., 2013; Souza et al., 2013; Leguen et al., 2015). This association supposes a benefit for both species (reciprocal protection from attacks of birds and other ants), so it could be considered as a mutualism. Moreover, other study carried out by Corbara and co-authors (2018) in French Guiana showed that nests of the arboreal wasp Protopolybia emortualis are found close to those of Dolichoredus bidens, an aggressive arboreal ant. This species protects wasps from attacks of army ants, which means a benefit for them but no for ants, so this association seems to be a kind of commensalism. As far as we know, it has not been previously recorded in Europe any case that demonstrates a possible relationship between ants and European hornets, Vespa crabro (L., 1758). Therefore, observations reported here might be the first that demonstrates a relationship between these insects.

The observations took place on November 23rd and 24th, 2018, in a nest-box population of spotless starling (Sturnus unicolor, Temminck 1820) located in central Spain 
(Soto del Real, Madrid; Lat. 40.451820, Long. -3.452038, alt. $920-940 \mathrm{~m}$. above sea level). Our study area is a holmoakdehesa ecosystem covered by a deciduous wood land of Quercus pyrenaica (Willd) and Fraxinus angustifolius (Tourn. ex L.), with intercalations of Acer monspessulanum (L.) and Crataegus monogyna (Jacq.), with abundant open areas used by a low load of bovine and equine cattle. This area exhibits a Continental Mediterranean climate (KöppenGeiger climate classification: Csb category (reviewed in Peel et al., 2007)) with hot and dry summers (Muriel et al., 2015). This starling colony consists of 246 nest-boxes and is located about 1.5-2.5 kilometres from Soto del Real. During both days, revisions of spotless starling nest-boxes were made in order to count how many of them were occupied by nests of European hornets. In two out of the seventeen nest-boxes $(11.67 \%)$ that contained hornet nests from the current year, it could be observed how a great number of Camponotus fallax (Nylander, 1856) specimens occupied their tops, just below the carton envelope. Both nest-boxes (separated from each other by a distance of $636.91 \mathrm{~m}$ ) were hooked on branches of two specimens of $Q$. pyrenaica (Lat. 40.7472077; Long. -3.8147455; alt. 924 m.and Lat. 40.7479135; Long. -3.8084156 , alt. $925 \mathrm{~m}$.), being located 3 metres above ground level, approximately. As a matter of fact, formicids appeared within the protective carton envelope, between the upper wall of the nest-box and the first comb of the nest. The first nest was occupied by several $V$. crabro specimens, whereas the second one was unoccupied, presenting a poor condition (incomplete combs and envelope). The nest deterioration could be a consequence of the destruction by starlings, which want to take possession of the nest-box after the reproductive cycle of $V$. crabro. In turn, the first nest contained a higher quantity of $C$. fallax specimens than the second one. In fact, in the first nest we found reproductive specimens (winged ants), larvae and workers (ca.250) (Fig 1a), whereas in the second nest only workers and very few larvae (ca. 25) were found (Fig 1b). This fact could be related to the abandonment of the nest by hornets or the cleaning of the nest-box by starlings. The occupation of avian nest-boxes by ants has been previously reported in Europe. Thus, Lambrechts and Schatz (2014) observed, in a study carried out in southern France, that some parid nest-boxes $(1.9 \%$ of bird nest-boxes in a rural woodland plot, and $16.7 \%$ in an urban plot) were occupied by C. fallax.

Taking into account previous studies, the case presented here does not seem to be related to any kind of predation (no ants were observed in the combs of the nest) or mutualism (there is no clear benefit for hornets as result of this relationship). However, it must be considered that $C$. fallax is a species with nocturnal habits (Yamamoto \& Del-Claro, 2008) and that the revisions were made during the day. Still, it is possible that C. fallax takes advantage of the protection and refuge that the nest-box and the hornet nest offer, or even of the microclimate generated by the envelope and the metabolism of pupae, larvae and adult of European hornets (Schmolz et al., 1995; Klingner et al., 2005). Thus, this association could be considered a kind of commensalism, similar to that described by Corbara and co-authors (2018), but resulting in a benefit for ants, not for hornets. In addition, ants could be using the honeydew produced by larvae as a source of food, thereby resulting in a case of trophobiosis. This mutualistic relationship is common between ants and insects 'Homoptera' (Delabie, 2001), and there are also reports of some species of Mutillidae that take advantage of the honeydew produced by the larvae of some Polistes wasps species (e.g. Uboni \& Lorenzini, 2013; MoraRubio \& Pérez-Bote, 2018). On the other hand, it is very likely that hornets were unaware of the existence of ants in their own nest, because $C$. fallax specimens were found within the outer envelope. Because of that, this relationship between ants and hornets could be described too as a case of plesiobiosis [original term introduced by Wheeler (1901)].

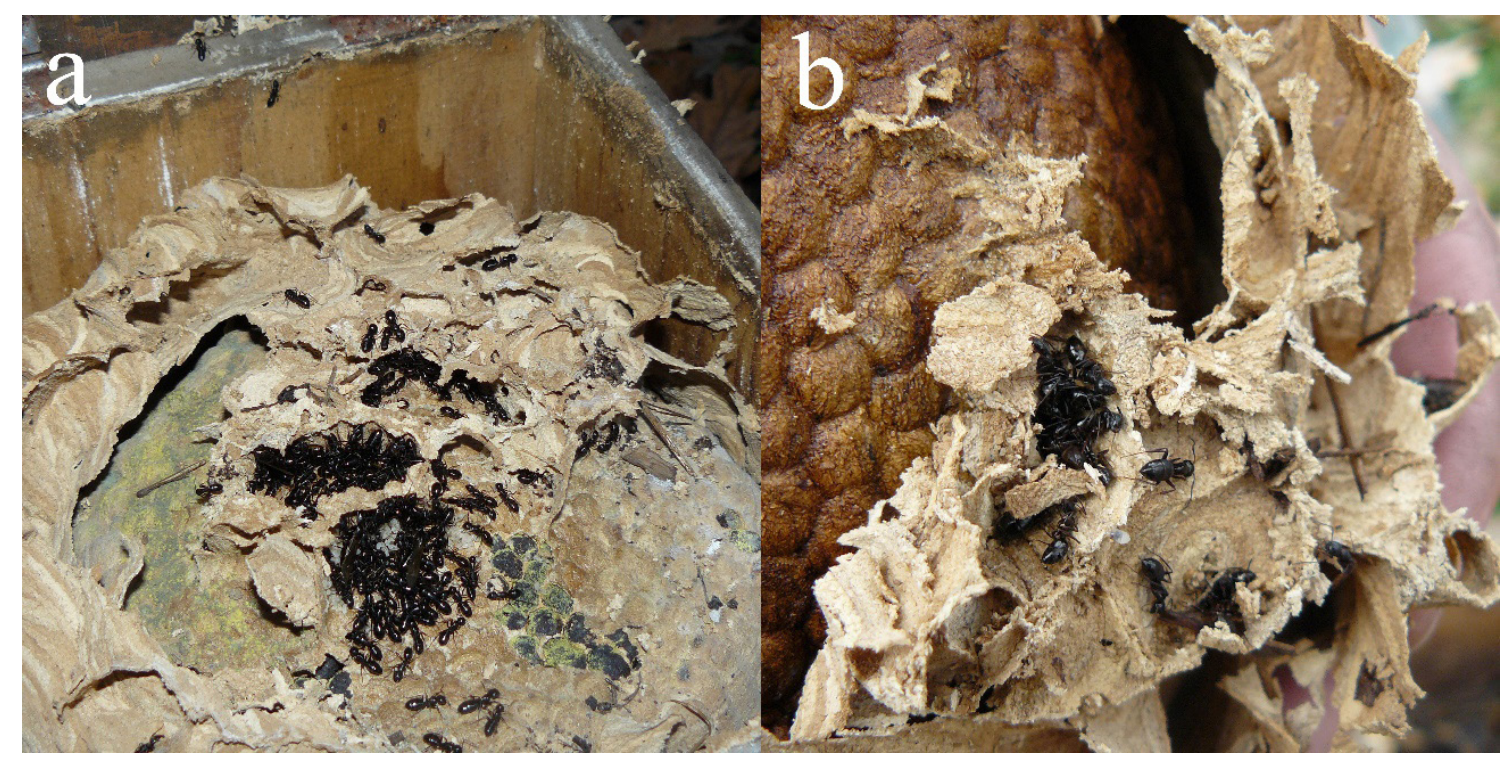

Fig 1. a: adults (workers and reproductive specimens) and larvae of Camponotus fallax in the first nest. b: workers on the second nest. 
It is defined as the occasional or regular closeness between nests of two colonies of social insects, without biological interdependence (low or no contact between both of them) (Kanizsai et al., 2013). This kind of association is common between ants (Czechowski \& Vepsäläinen, 1999; Kanizsai et al., 2013; Kvifte et al., 2017), but there are no observations of this relationship between ants and hornets. Thus, this would be the first report of plesiobiosis between these two groups. This interspecific tolerance could be a consequence of similar cuticular hydrocarbon profiles between $C$. fallax and $V$. crabro, since different studies have shown that several heterospecific insects are able to integrate into social insect colonies thanks to these surface hydrocarbons which play an important role in nestmate recognition (Howard et al., 1980; Vander Meer et al., 1989; Singer \& Espelie, 1992; Layton \& Espelie, 1994).

We report here the first European record on association between ants (C. fallax) and European hornets ( $V$. crabro). We have exposed all the possible interactions that could explain this association between both species throughout the text, but further studies should carry out more precise monitoring in order to determine what kind of interaction is really happening between these common hymenopterans of our forests.

\section{Acknowledgements}

We are very grateful to Dr. Diego Gil (MNCN-CSIC) for allowing us to sample the nest-box colony of spotless starlings (S. unicolor), which he has been monitoring since 2001; and Dr. Alberto Tinaut (University of Granada) for helping us in the proper identification of C. fallax. JM was supported by a postdoctoral contract from the University of Extremadura (Junta de Extremadura - IB16121). CM-R was supported by a collaboration grant from the MECD (Ministerio de Educación, Cultura y Deporte).

\section{Authors' Contributions}

$\mathrm{JM}$ and CM-R conceived the sampling designs; CM-R and JM collected data; CM-R wrote initial draft of the manuscript. JLP-B and JM contributed to subsequent revisions and gave final approval for publication.

\section{References}

Corbara, B., Servigne, P., Dejean, A., Carpenter, J.M. \& Orivel, J. (2018). A mimetic nesting association between a timid social wasp and an aggressive arboreal ant. Comptes Rendus Biologies, 341: 182-188. doi: 10.1016/j.crvi.2018.01.006

Czechowski, W. \& Vepsäläinen, K. (1999). Plesiobiosis between Formica fusca L. and Formica aquilonia Yarr.(Hymenoptera, Formicidae). Annales Zoologici (Warszawa) 49: 125-127.

Delabie, J.H.C. (2001). Trophobiosis between Formicidae and Hemiptera (Sternorrhyncha and Auchenorrhyncha): an overview. Neotropical Entomology, 30(4): 501-516. doi: 10.15 90/S1519-566X2001000400001

Jeanne, R.L. (1975). The adaptiveness of social wasp nest architecture. The Quarterly Review of Biology, 50(3): 267287. doi: $10.1086 / 408564$

Jeanne, R.L. (1979). A latitudinal gradient in rates of ant predation. Ecology, 60(6): 1211._doi: 10.2307/1936968

Kanizsai, O., Lörinczi, G. \& Gallé, L. (2013). Nesting Associations without Interdependence: A preliminary review of plesiobiosis in ants. Psyche, 2013: 238-602. doi: 10.1155/2013/238602

Klingner R., Richter K., Schmolz E. \& Keller B. (2005). The role of moisture in the nest thermoregulation of social wasps. Naturwissenschaften, 92: 427-430. doi: 10.1007/s00114-0050012-y

Kozyra, K.B. \& E. Baraniak (2016). Causes of mortality of Polistes nimpha colonies. InsectesSociaux, 63: 481-482. doi: 10.1007/s00040-016-0484-0

Kvifte, G.M., Legøy, T.A. \& Soulé, J. (2017). The Plesiobiontic Association of Formica lemani Bondroit with Lasius flavus (Fabricius) (Hymenoptera, Formicidae) in Norway. Sociobiology 64(3): 366-368. doi: 10.13102/sociobiology.v64i3.1030

Lambrechts, M.M. \& Schatz, B. (2014). Ants and Paridaeshare nesting boxes in continental Mediterranean habitat. Folia Zoologica, 63: 63-66. doi: 10.25225/fozo.v63.i2.a2.2014

Le Guen, R., Corbara, B., Rossi, V., Azémar, F. and Dejean, A. (2015) Reciprocal protection from natural enemies in antwasp association. Comptes Rendus Biologies, 338: 255-259. doi: 10.1016/j.crvi.2015.02.002

Mora-Rubio, C. \& Pérez-Bote, J.L. (2018). Observación de Tropidotillalitoralis (Petagna, 1787) (Hymenoptera, Mutillidae) sobre un nido de Polistes gallicus (Linnaeus, 1767) (Hymenoptera, Vespidae). Boletín de la Sociedad Entomológica Aragonesa, 63: 267-268.

Muriel, J., Salmón, P., Nunez-Buiza, A., de Salas, F., PérezRodríguez, L., Puerta, M. \& Gil, D. (2015). Context-dependent effects of yolk androgens on nestling growth and immune function in a multibrooded passerine. Journal of Evolutionary Biology, 28: 1476-1488. doi: 10.1111/jeb.12668

Peel MC, Finlayson BL, Mcmahon TA (2007). Updated world map of the Köppen-Geiger climate classification. Hydrology and Earth System Sciences Discussions, 4: 439-473. doi: 10.5194/hess-11-1633-2007

Pérez-Bote, J.L. \& Mora-Rubio, C. (2018). Un caso de depredación de nidos de Polistes gallicus (Linnaeus, 1767) (Hymenoptera: Vespidae) por Lasiusgrandis Forel, 1909 (Hym.: Formicidae). Boletín de la Sociedad Entomológica Aragonesa, 63: 274.

Rusina, L.Y. (2011). Some aspects of interrelations between ants (Hymenoptera, Formicidae) and polistine wasps 
(Hymenoptera, Vespidae). Entomological Review, 91: 241252. doi: 10.1134/S0013873811020126

Schatz, B., Proffit, M., Rakhi, B.V., Borges, R.M. \& HossaertMcKey, M. (2006). Complex interactions on fig trees: ants capturing parasitic wasps as possible indirect mutualists of the fig-fig wasp interaction. Oikos, 113: 344-352. doi: 10.1111/j.2006.0030-1299.13986.x

Schmolz, E., Lamprecht, I., \& Schricker, B. (1995). A method for continuous direct calorimetric measurements of energy metabolism in intact hornet (Vespa crabro) and honeybee (Apis mellifera) colonies. Thermochimica Acta, 251: 293301. doi: 10.1016/0040-6031(94)01965-J

Somavilla, A.; Fernandes, I.O.; Oliveira, M.L. \& Silveira, O.T. (2013). Association among wasps' colonies, ants and birds in Central Amazonian. Biota Neotropica, 13(2): 308313. doi: 10.1590/S1676-06032013000200031

Souza, M.M., Pires, E.P. \& Prezoto, F. (2013). Nidification of Polybia rejecta (Hymenoptera: Vespidae) associated to Azteca chartifex (Hymenoptera: Formicidae) in a fragment of Atlantic Forest, in the state of Minas Gerais, southeastern Brazil. Biota Neotropica, 13(3): 390-392. doi: 10.1590/ S1676-06032013000300038

Turillazzi, S. \& Ugolini, A. (1979). Rubbing behavior in some European Polistes (Hymenoptera: Vespidae). Monitore Zoologico Italiano, 13: 67-70.

Uboni, A. \& Lorenzi, M.C. (2013). Poor odors, strength, and persistence give their rewards to Mutillaeuropaea visiting dangerous wasp nests. Journal of Insect Behavior, 26: 246252. doi: 10.1007/s10905-012-9362-4

Wheeler, M.W. (1901). The compound and mixed nests of American ants. American Naturalist, 35: 1007-1016._doi: $10.1086 / 277948$

Yamamoto, M. \& Del-Claro, K. (2008). Natural history and foraging behavior of the carpenter ant Camponotus sericeiventris Guérin, 1838 (Formicinae, Campotonini) in the Brazilian Tropical Savanna. Acta Ethologica, 11: 55-65. doi: 10.1007/s10211-008-0041-6 